\title{
Effect of Nitrogen Management on Productivity and Mineral Nutrition of Ramie [Boehmeria nivea (L.) Gaud] and Properties of Soil
}

\author{
A.S.N. Zaman ${ }^{1}$, Biswajit Guha ${ }^{1}$, Sabyasachi Mitra ${ }^{2 *}$, S.P. Mazumdar ${ }^{2}$, A.R. Saha ${ }^{2}$, \\ Mukesh Kumar ${ }^{2}$, Monidipta Saha $^{3}$ and P. Bandopadhyay ${ }^{4}$ \\ ${ }^{1}$ Regional Agricultural Research Station, Assam Agricultural University, \\ Shillongani, Nagaon -782 002, Assam, India \\ ${ }^{2}$ ICAR-CRIJAF, Barrackpore, Kolkata, India \\ ${ }^{3}$ SS KVK, RKMVERI, Kolkata, India \\ ${ }^{4}$ Department of Agronomy, BCKV, India \\ *Corresponding author
}

\section{A B S T R A C T}

Keywords

Nitrogen, Ramie, Dry

biomass, Fibre yield,

Nutrient uptake, Ramie

waste, Soil fertility

Article Info

Accepted:

22 October 2018

Available Online:

10 November 2018

\begin{abstract}
Balanced fertilizer application is important for sustaining the productivity of ramie since the nutrient requirement of the crop is quite high due to its high biomass production. The present experiment was conducted at Nagaon, Assam, India from 2007 to 2009 to study the effect of varying levels of inorganic fertilizer nitrogen alone or in combination with crop residue, i.e., ramie waste on fibre yield and nutrient uptake by ramie, soil fertility and SOC concentration. The experimental data revealed that increasing the recommended dose of nitrogen in ramie from 100 to $150 \%$, i.e., from 30 to $45 \mathrm{~kg} / \mathrm{ha} /$ cutting increased the growth, fibre yield and nutrient uptake by the crop. Moreover at higher $\mathrm{N}$ dose $(45 \mathrm{~kg}$ ha/cutting), 50\% substitution of inorganic nitrogen through ramie waste further increased the growth, fibre productivity and nutrient uptake by the crop over inorganic nitrogen addition and also improved the fertility status of the soil and it also reduced application of fertilizer by $67-90 \mathrm{~kg} \mathrm{~N} / \mathrm{ha} /$ year.
\end{abstract}

\section{Introduction}

Ramie (Boehmeria nivea L. Gaud) is a perennial bast fibre crop belonging to Urticaceae family which produces one of the longest and strongest textile fibres of plant origin. Due to its unique blending property along with high tensile strength and resistance to bacterial degradation, ramie fibre is extensively used in textile sector. Globally ramie is cultivated in 0.066 million ha area with an annual production of 0.124 million tons of which China alone produces 0.119 million tones fibre per year (http://faostat.fao. org, 2013). In India, ramie is traditionally grown in Assam and other north-eastern states of the country but the production is insufficient to meet the domestic demand, due to poor acreage (Mitra et al., 2013) and the country imports significant quantity of ramie fibre, yarn and fabric every year.

Because of its high biomass production, ramie removes significant amount of nutrients from 
soil. Higher fibre productivity of ramie with increased level of $\mathrm{N}$ fertilization had been reported by Maity et al., (2007) and Tatar et al., (2010). Mandal et al., (1974) also reported that 153,18 and $78 \mathrm{~kg} \mathrm{~N}, \mathrm{P}$ and $\mathrm{K} /$ ha were removed from soil by ramie to produce one tonne $(1000 \mathrm{~kg})$ of raw fibre under rainfed condition in Assam. Thus the soil needs to be adequately fertilized to get higher fibre yield of the crop over a longer period of time.

The leaf and tender top portion of the stem which contains high amount of nitrogen (1.9 $3.5 \%$ ) is usually removed before fibre extraction and is not used commercially. This green biomass (tender tops and leaves) after proper decomposition, if applied to the soil along with chemical fertilizers, can effectively curtail the requirement of fertilizer nitrogen in ramie cultivation and thus can reduce the expenditure on fertilizer besides increasing fibre yield and improving properties of the soil. Thus, in this experiment, a part of the fertilizer nitrogen was supplied to ramie through organic source, i.e. ramie compost at both recommended and enhanced $\mathrm{N}$ supply levels, and the effect of this integrated nitrogen management on growth, fibre productivity and mineral nutrition of ramie along with the changes in fertility status of soil was studied in detail.

\section{Materials and Methods}

The experiment on ramie crop was conducted at the research farm of Regional Agricultural Research Station, Shillongani, Nagaon, Assam from 2007 to 2009. The experimental field was located at $26^{\circ} 21^{\prime} 48^{\prime \prime} \mathrm{N}$ latitude, and $92^{0} 38^{\prime} 31^{\prime \prime} \mathrm{E}$ longitude at an elevation of about 50.2 meter above the mean sea level. The soil was well drained Aeric Haplaquept, sandy clay loam in texture, having $\mathrm{pH} 5.43$, organic carbon $7.3 \mathrm{~g} / \mathrm{kg}$, available N $290.7 \mathrm{~kg} / \mathrm{ha}$, available $\mathrm{P} 10.6 \mathrm{~kg} / \mathrm{ha}$ and available $\mathrm{K} 116.7$ $\mathrm{kg} / \mathrm{ha}$, respectively. The crop received 1910.2,
1543.2 and $1207.2 \mathrm{~mm}$ rainfall during 2007 , 2008 and 2009, respectively as against the normal annual rainfall of $1829.7 \mathrm{~mm}$ (average of 39 years). The field experiment was conducted in a randomized block design with three replications. The treatments for this study consisted of (i) $\mathrm{T}_{1}: 100 \%$ recommended dose of nitrogen (RDN) of which $50 \% \mathrm{~N}$ was applied through ramie waste composted (RW); (ii) $\mathrm{T}_{2}: 100 \% \mathrm{RDN}$ of which $25 \% \mathrm{~N}$ was applied through RW; (iii) $\mathrm{T}_{3}: 100 \% \mathrm{RDN}$ in inorganic form; (iv) $\mathrm{T}_{4}: 150 \%$ RDN of which $50 \% \mathrm{~N}$ was applied through RW; (v) $\mathrm{T}_{5}: 150 \%$ RDN of which $25 \% \mathrm{~N}$ was applied through $\mathrm{RW}$; (vi) $\mathrm{T}_{6}: 150 \% \mathrm{~N}$ in inorganic form and (vii) $\mathrm{T}_{7}$ : control (no externally applied nitrogen). The recommended dose of fertilizer for ramie is $30 \mathrm{~kg} \mathrm{~N}, 15 \mathrm{~kg} \mathrm{P}_{2} \mathrm{O}_{5}, 15 \mathrm{~kg}$ $\mathrm{K}_{2} \mathrm{O} / \mathrm{ha}$, to be applied after each cutting (Mitra et al., 2013). A uniform dose of $15 \mathrm{~kg} \mathrm{P}_{2} \mathrm{O}_{5}$ and $15 \mathrm{~kg} \mathrm{~K}_{2} \mathrm{O} \mathrm{ha}^{-1}$ was applied to all plots after each cutting while nitrogen was applied to the experimental plots as per treatment. The ramie waste used in the experiment comprised of green leaves and top succulent portion of the stem removed before fibre extraction and it contained $1.9-2.5 \% \mathrm{~N}, 0.26-0.30 \% \mathrm{P}$ and $1.3-2.0 \% \mathrm{~K}$ after composting as observed during the experimental period. The rhizomes of ramie cultivar R-67-34 was planted with an inter row spacing of $0.6 \mathrm{~m}$ and intra row spacing of $0.3 \mathrm{~m}$ in May, 2007. Sprouting was observed from 15 days after planting and gap filling (need based) was done subsequently within first week of June to develop a uniform plant population of 55000 plants/ha. In the establishment year (2007), three cuttings could be done while in subsequent years four cuttings could be taken at an interval of 45-55 days. The above ground biomass (leaf, bark and wood portion of the plant samples) were oven dried at $70^{\circ} \mathrm{C}$ for 48 hours to determine the respective dry matter yields. The weight of oven dried leaf, bark and wood of individual samples were added to obtain total dry matter of the plant and was 
expressed in $\mathrm{kg} / \mathrm{ha}$. The raw fibre extracted mechanically from defoliated canes were then washed with clean water and sundried and the yield was expressed in tonnes/ha. The plant samples (leaf, wood and bark) were oven dried at $70^{\circ} \mathrm{C}$, processed and analyzed for total $\mathrm{N}, \mathrm{P}$ and $\mathrm{K}$ following standard procedures Kjeldahl N digestion-distillation, spectrophotometer based phosphoammonium-molybdate, and flame photometry methods, respectively. The nutrient concentration of wood, bark and leaves were multiplied by their corresponding dry yields and uptakes of various plant parts were determined accordingly. Similarly, initial and the post-harvest soil samples were collected at the beginning and after the harvest of the final cutting every year, dried, processed and analyzed for oxidizable organic $\mathrm{C}$ by Walkley and Black method; available $\mathrm{N}$ by alkaline permanganate method; available P by Bray's method and available K by flame photometer following standard procedures (Jackson 1967). The data on dry matter, fibre yield and chemical analysis of plant and soil samples were analyzed using ANOVA as per the procedure outlined by Gomez and Gomez (1984). The significant difference among the means of different treatments was analyzed by Duncan's Multiple-Range Test using SAS v 9.2.

\section{Results and Discussion}

\section{Above ground biomass and fibre yield}

The perusal of data on above ground biomass of ramie revealed that almost all the nutrient treatments recorded significantly higher biomass and fibre yield of ramie over control (Table 1). The treatments comprising of $150 \%$ $\mathrm{N}$ either alone or in combination with ramie waste $\left(\mathrm{T}_{4}, \mathrm{~T}_{5}\right.$ and $\left.\mathrm{T}_{6}\right)$ recorded more dry biomass as compared to $100 \% \mathrm{~N}$ treatments $\left(\mathrm{T}_{1}, \mathrm{~T}_{2}\right.$ and $\left.\mathrm{T}_{3}\right)$ in all the cuttings in 2008 and 2009, while in 2007, similar trend was observed in the later stage, i.e., in the $3^{\text {rd }}$ cutting only. In the first year, a decreasing trend in biomass accumulation of ramie was observed when part of the inorganic nitrogen was substituted by ramie waste at both 100 and $150 \% \mathrm{~N}$ application level. From second cutting of 2008 onwards, substitution of inorganic nitrogen through ramie waste to the tune of $25-50 \%$ recorded dry biomass of ramie which was statistically at par to that with inorganic nitrogen treatments (100 and $150 \%)$ in all the cuttings. The INM treatments showed an increasing trend in biomass accumulation compared to the inorganic treatments both at 100 and $150 \% \quad \mathrm{~N}$ application level in all the cuttings in 2009. Similar trend was observed in case of total annual dry matter yield also (Table 1). The increased plant height with more number of stems in $\mathrm{T}_{4}$ and $\mathrm{T}_{5}$ treatments (data not shown), particularly during the later phase of growth, might have increased the biomass of ramie crop compared to inorganic nitrogen treatment. The higher biomass accumulation in ramie in INM treatments compared to inorganic treatments in the subsequent years could be due to better decomposition of ramie compost in course of time resulting into higher nutrient availability to ramie plants when 25 to $50 \%$ of inorganic $\mathrm{N}$ was substituted with ramie compost. Higher biomass accumulation in ramie through integrated nutrient management had been reported by Mitra et al., (2014) also.

Increasing the recommended nitrogen level from $100 \%$ to $150 \%$, either in inorganic form or as a combination of inorganic and organic, significantly increased the fibre yield of ramie except in the first two cuttings in 2007 (Table 2). Maximum fibre yield of the crop was recorded in second cutting followed by the third in all the years of experimentation. In the establishment year (2007), maximum annual fibre yield (1.32 tonnes/ha) was observed in $\mathrm{T}_{6}$ treatment $(150 \% \mathrm{~N}$ as inorganic only) which 
was statistically at par with $\mathrm{T}_{5}$ treatment (1.20 tonnes/ha) when $25 \%$ of the inorganic $\mathrm{N}$ was replaced by ramie waste. Almost similar trend in fibre yield was also observed in the individual cuttings in the first year. From the second year onward, no significant variation in fibre yield of ramie was observed in the individual cuttings as well as in the total annual yield of the crop, when inorganic nitrogen was substituted by ramie waste to the tune of 25 to $50 \%$ at both 100 and $150 \% \mathrm{~N}$ application levels (Table 2). Rather, an increasing trend in fibre yield was recorded with the combined nitrogen treatments compared to the inorganic nitrogen treatments (100 and $150 \%$ RDN) with time. It was evident from the results that during the initial year, application of ramie compost did not influence the increase in fibre yield of ramie consistently at both the levels of nitrogen application while in the subsequent years, use of ramie compost as a substitution of inorganic nitrogenous fertilizer increased the fibre yield of the crop and also reduced the use of chemical fertilizer. As stated earlier, the increased availability of nutrients in INM treated plots compared to inorganic plots (both 100 and $150 \%$ RDN) produced higher biomass, which in turn positively influenced the fibre yield of the crop. Increase in fibre yield of ramie through integrated nutrient management using ramie compost was reported earlier (Maity et al., 2007; Mitra et al., 2014).

\section{Nutrient Uptake}

The data on total annual uptake of N, P and K by ramie are presented in table 3 . All the nutrient treatments recorded significantly higher nutrient uptake by ramie over the unfertilized control in all the years. During the first year (2007), maximum $\mathrm{N}$ uptake (36.12 $\mathrm{kg} / \mathrm{ha}$ ) was recorded with $\mathrm{T}_{6}$ treatment $(150 \%$ inorganic nitrogen) though it was statistically at par with $\mathrm{T}_{5}(150 \% \mathrm{~N}, 25 \%$ from ramie waste) treatment. In 2008, it was observed that at lower (100\%) nitrogen application level, the INM treatments with 25 to $50 \%$ substitution of inorganic $\mathrm{N}$ by ramie compost $\left(\mathrm{T}_{1}\right.$ and $\left.\mathrm{T}_{2}\right)$ recorded significantly lesser nitrogen uptake by the crop $(66.85-72.02 \mathrm{~kg} / \mathrm{ha})$ as compared to the sole inorganic $\mathrm{N}$ treatment $\left(\mathrm{T}_{3}\right)(81.12$ $\mathrm{kg} / \mathrm{ha})$ while at higher nitrogen level $(150 \%$ $\mathrm{N})$, the INM treatments $\left(\mathrm{T}_{4}\right.$ and $\left.\mathrm{T}_{5}\right)$ were statistically at par with $150 \%$ inorganic $\mathrm{N}$ treatment $\left(\mathrm{T}_{6}\right)$ in this regard. In 2009 , the $\mathrm{N}$ uptake by the crop with INM treatments were statistically at par to that with inorganic nitrogen treatment at $100 \%$ nitrogen level while at $150 \% \mathrm{~N}$ level, the INM treatment $\mathrm{T}_{4}$ $(50 \%$ substitution of inorganic $\mathrm{N})$ even recorded significantly higher nitrogen uptake $(180.95 \mathrm{~kg} / \mathrm{ha})$ as compared to $150 \%$ inorganic nitrogen treatment $(166.66 \mathrm{~kg} / \mathrm{ha})$ (Table 3).

The higher annual uptake of nitrogen in ramie compost treatments in 2009 as compared to 2008 might be attributed to increased microbial activity in the INM treated plots over time which had favoured the mineralization of organic nitrogen to inorganic form and facilitated the uptake by the crop (Mitra et al., 2006; Mitra et al., 2010). Almost similar trends were observed in phosphorus and potassium uptake by ramie. Substitution of inorganic nitrogen by 25 to $50 \%$ through ramie compost increased phosphorus and potassium uptake by ramie over inorganic $\mathrm{N}$ treatments particularly at $150 \% \mathrm{~N}$ level. Maximum $\mathrm{P}$ uptake was recorded with $\mathrm{T}_{5}$ treatment in $2007(15.75 \mathrm{~kg} / \mathrm{ha})$ and in 2008 $(15.42 \mathrm{~kg} / \mathrm{ha})$ and with $\mathrm{T}_{4}$ treatment in 2009 $(26.23 \mathrm{~kg} / \mathrm{ha})$ while maximum $\mathrm{K}$ uptake was recorded with $\mathrm{T}_{4}$ treatment, in all the years of experimentation (Table 3 ). The integration of organic manure in fertilizer schedule might have led to enhanced mineralization or had increased root growth due to improved soil physical conditions which in turn increased the nutrient uptake by the crop. 
Table.1 Total above ground dry biomass of ramie as influenced by nutrient treatments

\begin{tabular}{|c|c|c|c|c|c|c|c|c|c|c|c|c|c|c|}
\hline \multirow[t]{3}{*}{ Treatments } & \multicolumn{14}{|c|}{ Above ground dry biomass of ramie (kg/ha) } \\
\hline & \multicolumn{4}{|c|}{2007} & \multicolumn{5}{|c|}{2008} & \multicolumn{5}{|c|}{2009} \\
\hline & $1^{\text {st }}$ cut & $2^{\text {nd }}$ cut & $3^{\text {rd }}$ cut & total & $1^{\text {st }}$ cut & $2^{\text {nd }}$ cut & $3^{\text {rd }}$ cut & $4^{\text {th }}$ cut & total & $1^{\text {st }}$ cut & $2^{\text {nd }}$ cut & $3^{\text {rd }}$ cut & $4^{\text {th }}$ cut & total \\
\hline$\overline{T_{1}}$ & $1436.16^{\mathrm{d}}$ & $1889.12^{\mathrm{c}}$ & $1209.80^{\mathrm{d}}$ & $4535.08^{\mathrm{d}}$ & $1619.42^{\mathrm{d}}$ & $2663.25^{\mathrm{b}}$ & $1847.18^{\mathrm{b}}$ & $1934.53^{b}$ & $8064.38^{\mathrm{b}}$ & $2047.32^{\mathrm{b}}$ & $3004.54^{\mathrm{d}}$ & $2425.82^{\mathrm{b}}$ & $2316.33^{\mathrm{b}}$ & $9794.01^{\mathrm{b}}$ \\
\hline$\overline{T_{2}}$ & $1705.66^{\mathrm{c}}$ & $2247.03^{\mathrm{bc}}$ & $1452.80^{\mathrm{d}}$ & $5405.49^{c}$ & $1779.81^{\mathrm{d}}$ & $2673.75^{\mathrm{b}}$ & $1781.25^{\mathrm{b}}$ & $1774.68^{\mathrm{c}}$ & $8009.49^{b}$ & $1925.00^{\mathrm{b}}$ & $2953.72^{\mathrm{d}}$ & $2194.40^{\mathrm{b}}$ & $2134.02^{\mathrm{b}}$ & $9207.14^{b}$ \\
\hline$\overline{T_{3}}$ & $1934.90^{\mathrm{bc}}$ & $2682.06^{\mathrm{b}}$ & $1761.81^{\mathrm{c}}$ & $6378.77^{b}$ & $2031.40^{c}$ & $2930.75^{b}$ & $1804.3^{\mathrm{b}}$ & $1934.53^{b}$ & $8700.98^{b}$ & $1935.12^{b}$ & $2913.02^{\mathrm{d}}$ & $2250.03^{b}$ & $2070.81^{\mathrm{b}}$ & $9168.98^{\mathrm{b}}$ \\
\hline $\mathbf{T}_{4}$ & $1705.66^{\mathrm{c}}$ & $2985.46^{\mathrm{ab}}$ & $2222.20^{\mathrm{b}}$ & $6913.32^{\mathrm{b}}$ & $2212.76^{\mathrm{bc}}$ & $3388.51^{\mathrm{a}}$ & $2122.11^{\mathrm{a}}$ & $2165.22^{\mathrm{a}}$ & $9888.6^{\mathrm{a}}$ & $2762.76^{\mathrm{a}}$ & $3506.36^{\mathrm{ab}}$ & $3034.82^{\mathrm{a}}$ & $2841.31^{\mathrm{a}}$ & $12145.25^{\mathrm{a}}$ \\
\hline$T_{5}$ & $1871.54^{\mathrm{c}}$ & $3133.42^{\mathrm{ab}}$ & $2274.82^{b}$ & $7279.78^{b}$ & $2327.38^{b}$ & $3439.25^{\mathrm{a}}$ & $2012.1^{\mathrm{ab}}$ & $2076.44^{\mathrm{ab}}$ & $9855.17^{\mathrm{a}}$ & $2711.72^{\mathrm{a}}$ & $3483.26^{\mathrm{bc}}$ & $2916.60^{\mathrm{a}}$ & $2780.61^{\mathrm{a}}$ & $11892.19^{\mathrm{a}}$ \\
\hline$\overline{T_{6}}$ & $2368.08^{\mathrm{a}}$ & $3468.88^{\mathrm{a}}$ & $2554.23^{\mathrm{a}}$ & $8391.19^{\mathrm{a}}$ & $2633.22^{\mathrm{a}}$ & $3539.25^{\mathrm{a}}$ & $2122.11^{\mathrm{a}}$ & $2182.93^{\mathrm{a}}$ & $10477.51^{\mathrm{a}}$ & $2622.62^{\mathrm{a}}$ & $3300.12^{c}$ & $2865.8^{\mathrm{a}}$ & $2668.68^{\mathrm{a}}$ & $11457.22^{\mathrm{a}}$ \\
\hline $\mathbf{T}_{7}$ & $1100.05^{\mathrm{e}}$ & $1408.42^{c}$ & $1481.20^{\mathrm{d}}$ & $3989.67^{\mathrm{d}}$ & $1280.84^{\mathrm{e}}$ & $1696.00^{c}$ & $1330.38^{c}$ & $1508.57^{\mathrm{d}}$ & $5815.79^{c}$ & $1247.62^{c}$ & $1628.24^{\mathrm{e}}$ & $1585.6^{c}$ & $1355.47^{\mathrm{c}}$ & $5816.93^{c}$ \\
\hline \multicolumn{15}{|c|}{ 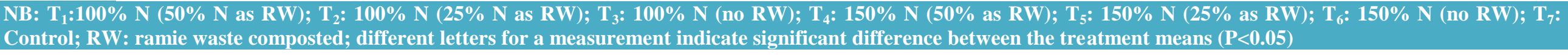 } \\
\hline \multicolumn{15}{|c|}{ Table.2 Fibre yield of ramie as influenced by nutrient treatments } \\
\hline \multirow{3}{*}{$\begin{array}{l}\text { Treatment } \\
\mathrm{s}\end{array}$} & \multicolumn{14}{|c|}{ Fibre yield (ton/ha) } \\
\hline & \multicolumn{4}{|c|}{2007} & \multicolumn{5}{|c|}{2008} & \multicolumn{5}{|c|}{2009} \\
\hline & $1^{\text {st }}$ cut & $2^{\text {nd }}$ cut & $3^{\text {rd }}$ cut & Total & $1^{\text {st }}$ cut & $2^{\text {nd }}$ cut & $3^{\text {rd }}$ cut & $4^{\text {th }}$ cut & Total & $1^{\text {st }}$ cut & $2^{\text {nd }}$ cut & $3^{\text {rd }}$ cut & $4^{\text {th }}$ cut & Total \\
\hline $\mathrm{T}_{1}$ & $0.16^{\mathrm{d}}$ & $0.44^{b}$ & $0.22^{\mathrm{cd}}$ & $0.82^{\mathrm{d}}$ & $0.34^{\mathrm{cd}}$ & $0.46^{\mathrm{b}}$ & $0.42^{b c}$ & $0.30^{\mathrm{ab}}$ & $1.51^{\mathrm{b}}$ & $0.35^{\mathrm{b}}$ & $0.54^{\mathrm{b}}$ & $0.45^{\mathrm{bc}}$ & $0.39^{b c}$ & $1.72^{b}$ \\
\hline $\mathbf{T}_{2}$ & $0.24^{\mathrm{bc}}$ & $0.58^{\mathrm{a}}$ & $0.23^{c}$ & $1.05^{\mathrm{c}}$ & $0.36^{\mathrm{bc}}$ & $0.44^{\mathrm{b}}$ & $0.40^{\mathrm{cd}}$ & $0.27^{\mathrm{bc}}$ & $1.47^{\mathrm{b}}$ & $0.32^{b}$ & $0.52^{\mathrm{bc}}$ & $0.39^{\mathrm{d}}$ & $0.35^{\mathrm{c}}$ & $1.58^{\mathrm{c}}$ \\
\hline$T_{3}$ & $0.27^{\mathrm{b}}$ & $0.56^{\mathrm{a}}$ & $0.27^{\mathrm{bc}}$ & $1.10^{\mathrm{bc}}$ & $0.36^{\mathrm{bc}}$ & $0.46^{\mathrm{b}}$ & $0.37^{\mathrm{cd}}$ & $0.26^{\mathrm{c}}$ & $1.45^{\mathrm{b}}$ & $0.33^{b}$ & $0.52^{b c}$ & $0.40^{\mathrm{cd}}$ & $0.34^{\mathrm{c}}$ & $1.60^{\mathrm{bc}}$ \\
\hline $\mathbf{T}_{4}$ & $0.21^{\mathrm{c}}$ & $0.44^{b}$ & $0.36^{\mathrm{ab}}$ & $1.01^{\mathrm{c}}$ & $0.45^{\mathrm{ab}}$ & $0.60^{\mathrm{a}}$ & $0.50^{\mathrm{a}}$ & $0.32^{\mathrm{a}}$ & $1.86^{\mathrm{a}}$ & $0.45^{\mathrm{a}}$ & $0.64^{\mathrm{a}}$ & $0.53^{\mathrm{a}}$ & $0.47^{\mathrm{a}}$ & $2.09^{a}$ \\
\hline$T_{5}$ & $0.25^{\mathrm{bc}}$ & $0.57^{\mathrm{a}}$ & $0.38^{\mathrm{a}}$ & $1.20^{\mathrm{ab}}$ & $0.47^{\mathrm{a}}$ & $0.58^{\mathrm{a}}$ & $0.47^{\mathrm{ab}}$ & $0.32^{\mathrm{a}}$ & $1.85^{\mathrm{a}}$ & $0.44^{\mathrm{a}}$ & $0.63^{\mathrm{a}}$ & $0.51^{\mathrm{a}}$ & $0.47^{\mathrm{a}}$ & $2.05^{\mathrm{a}}$ \\
\hline $\mathrm{T}_{6}$ & $0.32^{\mathrm{a}}$ & $0.61^{\mathrm{a}}$ & $0.39^{\mathrm{a}}$ & $1.32^{\mathrm{a}}$ & $0.45^{\mathrm{ab}}$ & $0.57^{\mathrm{a}}$ & $0.50^{\mathrm{a}}$ & $0.33^{\mathrm{a}}$ & $1.85^{\mathrm{a}}$ & $0.44^{\mathrm{a}}$ & $0.61^{\mathrm{a}}$ & $0.50^{\mathrm{ab}}$ & $0.44^{\mathrm{ab}}$ & $1.98^{\mathrm{a}}$ \\
\hline $\mathbf{T}_{7}$ & $0.13^{\mathrm{d}}$ & $0.34^{\mathrm{b}}$ & $0.17^{\mathrm{d}}$ & $0.64^{\mathrm{e}}$ & $0.24^{\mathrm{d}}$ & $0.35^{\mathrm{c}}$ & $0.34^{\mathrm{d}}$ & $0.20^{\mathrm{d}}$ & $1.14^{\mathrm{c}}$ & $0.20^{c}$ & $0.47^{\mathrm{c}}$ & $0.36^{\mathrm{d}}$ & $0.27^{\mathrm{d}}$ & $1.31^{d}$ \\
\hline
\end{tabular}

NB: $T_{1}: 100 \% \mathrm{~N}\left(50 \% \mathrm{~N}\right.$ as RW); $\mathrm{T}_{2}: 100 \% \mathrm{~N}\left(25 \% \mathrm{~N}\right.$ as RW); $\mathrm{T}_{3}: 100 \% \mathrm{~N}$ (no RW); $\mathrm{T}_{4}: 150 \% \mathrm{~N}\left(50 \%\right.$ as RW); $\mathrm{T}_{5}: 150 \% \mathrm{~N}(25 \%$ as RW);

$\mathrm{T}_{6}: 150 \% \mathrm{~N}$ (no $\mathrm{RW}$ ); $\mathrm{T}_{7}$ : Control; $\mathrm{RW}$ : ramie waste composted; different letters for a measurement indicate significant difference between the treatment means $(\mathbf{P}<0.05)$ 
Table.3 Total annual uptake of N, P and K by ramie plants as influenced by nutrient treatments

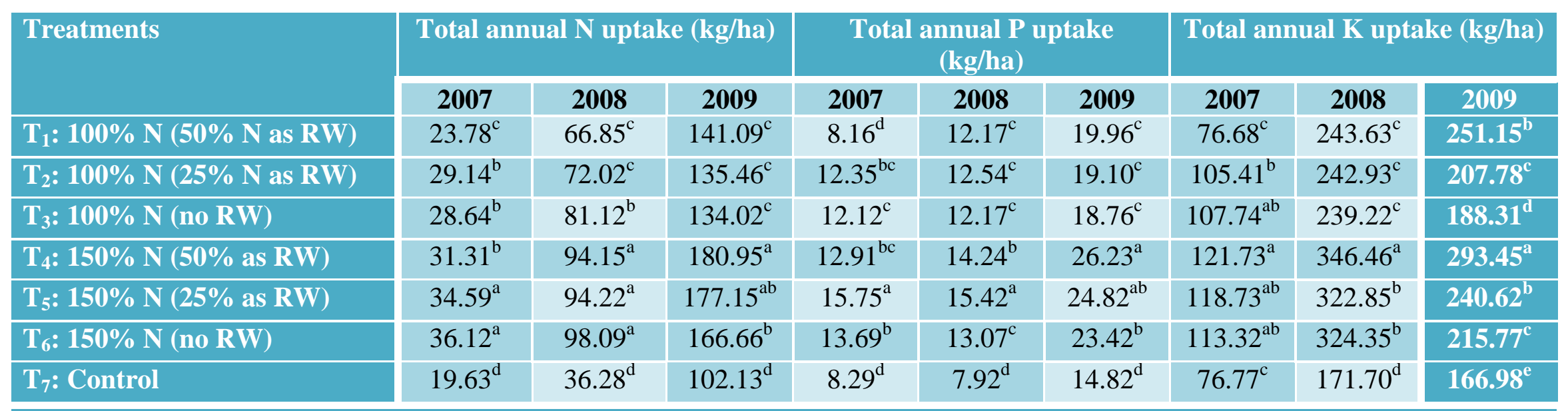

NB: RW: ramie waste composted; different letters for a measurement indicate significant difference between the treatment means $(\mathbf{P}<0.05)$

Table.4 Soil organic carbon and available nutrient status of experimental soil during the growth period of ramie

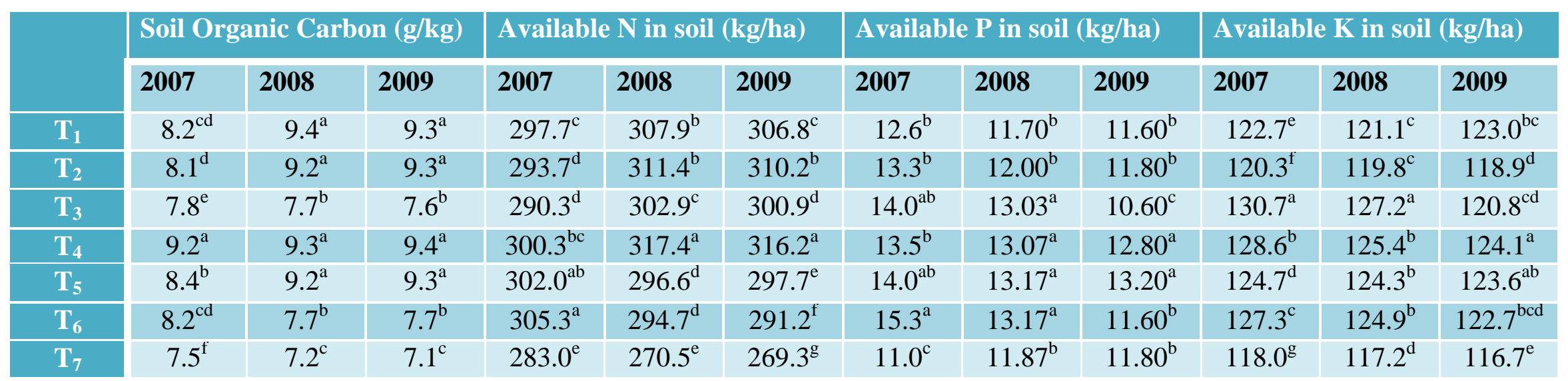

NB: $\mathrm{T}_{1}: 100 \% \mathrm{~N}\left(50 \% \mathrm{~N}\right.$ as RW); $\mathrm{T}_{2}: 100 \% \mathrm{~N}\left(25 \% \mathrm{~N}\right.$ as RW); $\mathrm{T}_{3}: 100 \% \mathrm{~N}$ (no RW); $\mathrm{T}_{4}: 150 \% \mathrm{~N}\left(50 \%\right.$ as RW); $\mathrm{T}_{5}: 150 \% \mathrm{~N}\left(25 \%\right.$ as RW); $\mathrm{T}_{6}: 150 \% \mathrm{~N}$ (no $\mathrm{RW}) ; \mathrm{T}_{7}$ : Control; RW: ramie waste composted; different letters for a measurement indicate significant difference between the treatment means $(\mathrm{P}<0.05)$ At planting of ramie (May 2007) (initial value) soil organic C, available N, P and K in soil was $7.3 \mathrm{~g} / \mathrm{kg}$ and 290.7, 10.6 and $116.7 \mathrm{~kg} / \mathrm{ha}$, respectively; 
Moreover, the higher $\mathrm{K}$ content in ramie compost possibly had increased the availability of potassium in soil and facilitated its uptake by the crop. Similar increase in phosphorus and potassium uptake due to integrated nutrient management had also been reported in jute (Mitra et al., 2010), roselle (Saha et al., 2008), wheat (Mitra et al., 2006) and in jute-rice cropping system (Singh et al., 2015). The nutrient uptake by ramie was found to be more at higher (150\%) nitrogen supply level with both inorganic and INM treatments in all the years of experimentation.

\section{Soil Fertility Status}

Three years of ramie cultivation with different nutrient management practices significantly influenced the chemical parameters of the soil. It is evident that soil organic carbon (SOC) increased significantly due to various nutrient management treatments in all the growth stages of ramie as compared to unfertilized control. The SOC in the experimental plots receiving INM treatments improved significantly compared to the plots receiving inorganic $\mathrm{N}$ alone (Table 4). This may be due to higher addition of $C$ inputs (Singh and Dhar, 2011) in INM treatments or may be due to their stimulating effect on growth and activity of soil microbes as reported by Kang et al., (2005). The SOC in the control plots did not change much compared to the initial value during the experimental period. The experimental data revealed that there was depletion in available nitrogen in the control (unfertilized) plots in comparison to its initial status possibly because of mining of nutrients due to continuous cropping of ramie without any fertilization over the years. The INM treatments increased the available nitrogen content in soil over sole inorganic treatments at both levels of nitrogen application in all the years except in 2007 when the INM treatments could not increase soil available $\mathrm{N}$ status over inorganic treatment particularly at $150 \% \mathrm{~N}$ application level. Maximum value of soil available $\mathrm{N}$ was recorded when $50 \%$ of the inorganic nitrogen was replaced though ramie waste at $150 \% \mathrm{~N}$ application level $\left(\mathrm{T}_{4}\right)$ during 2008 and 2009 (Table 4). The increase in available nitrogen in the plots receiving INM treatments may be attributed to the direct addition of nitrogen in inorganic form along with its release through mineralization of organic, i.e. ramie compost in course of time. The results are in conformity with the earlier research findings in jute (Majumdar et al., 2014), roselle (Saha et al., 2008) and jute - rice cropping system (Singh et al., 2015). The available phosphorus content of soil in the INM treated plots were statistically at par with that of plots receiving inorganic nitrogen at $150 \% \mathrm{~N}$ application level (Table 4). Build up in available P with INM treatments was ascribed to the release of organic acids during decomposition of ramie compost which in turn helped in solubilization and release of native phosphorus by these acids. Further, the organic matter added to soil forms a coating on sesquioxides and makes them inactive and thus reduces the P-fixation, which is a major problem in soils in Assam, and ultimately helps in increasing the available $\mathrm{P}$ in soil.

Increase in available $\mathrm{P}$ content in soil receiving INM treatments had also been reported in other fibre crops such as jute (Majumdar et al., 2014) and sunnhemp (Maitra et al., 2008). Similarly, substitution of inorganic nitrogen through ramie compost also increased the soil available K over sole inorganic treatment at $150 \% \mathrm{~N}$ level though the increases were not always significant (Table 4). Increase in available $\mathrm{K}$ due to addition of ramie compost may be ascribed to the reduction of $\mathrm{K}$ fixation and release of $\mathrm{K}$ due to interaction of organic matter with clays, besides the direct potassium addition to soil. Increased availability of $\mathrm{K}$ in soil due to incorporation of organics in fertilizer schedule had been reported earlier in jute (Mitra et al., 2010) and in jute - rice system (Singh et al., 2015).

The present study clearly indicated that increase in nitrogen dose of ramie from 30 to $45 \mathrm{~kg}$ $\mathrm{N} / \mathrm{ha} /$ cutting, significantly increased growth, fibre yield and nutrient uptake by the crop. After three years of experimentation, it was also 
evident from our study that at the higher (150\%) nitrogen application level, i.e. $45 \mathrm{~kg}$ $\mathrm{N} /$ ha/cutting, substitution of inorganic $\mathrm{N}$ to the tune of $50 \%$ through ramie compost (leaves and tender twigs cut before extraction and composted) further increased the growth, fibre productivity and nutrient uptake by the crop over sole inorganic nitrogen treatment and also improved the fertility status of the soil. Moreover, the inclusion of ramie compost reduced the use of inorganic fertilizer nitrogen in ramie by $22.5 \mathrm{~kg} \mathrm{~N} / \mathrm{ha} /$ cutting or by $67-90 \mathrm{~kg}$ $\mathrm{N} / \mathrm{ha} /$ year. Thus the incorporation of ramie compost in fertilizer schedule of ramie needs to be promoted to attain higher and stable fibre productivity of the crop, maintain the fertility status of the soil and to reduce the consumption of inorganic fertilizer nitrogen in ramie cultivation.

\section{Acknowledgement}

The authors acknowledge Ministry of Textile, Government of India for providing financial support for this research programme under Technology Mission for Jute, Mini Mission I. The authors are also grateful to Vice Chancellor, Assam Agricultural University, Jorhat, Assam, India and Director, ICARCentral Research Institute for Jute and Allied Fibre, Barrackpore, Kolkata, India for providing necessary support for conducting the research programme successfully.

\section{References}

Angelini, L. G., and Tavarini, S. 2013. Ramie [Boehmeria nivea (L.) Gaud.] as a potential new fibre crop for the Mediterranean region: Growth, crop yield and fibre quality in a long-term field experiment in Central Italy. Industrial Crops and Products, 51:138-144.

Gomez, K.A., Gomez, A.A. 1984. Statistical Procedures for Agricultural Research. Wiley Interscience, New York.

Huang, Chengjian, Wei, Gang, Luo, Zizi, Xu, Jianjun, Zhao, Siyi, Wang, Longchang and Yucheng, Jie. 2014. Effects of nitrogen on ramie (Boehmeria nivea) hybrid and its parents grown under field conditions. Journal of Agricultural Science, 6(12): 230-243.

Jackson, M., L. 1967. Soil Chemical Analysis, Prentice Hall of India Pvt. Ltd, New Delhi.

Kang, G.S., Beri, V., Rupela, O.P. and Sidhu, B.S. 2005. A new index to assess soil quality and sustainability of wheat based cropping systems. Biology and Fertility of Soils, 41: 389-398.

Maitra, D. N., Sarkar, S. K., Saha, S., Tripathy, M. K., Majumdar, B. and Saha, A. R. 2008. Effect of phosphorus and farmyard manure applied to sunnhemp (Crotalaria juncea) on yield and nutrient uptake of sunnhemp-wheat (Triticum aestivum) cropping system and fertility status in a Typic Ustochrept of Uttar Pradesh. Indian Journal of Agricultural Sciences, 78 (1): 70-74.

Maity, S. K., Karmakar, S. and Mukherjee, P. K. 2007. Response of ramie (Boehmeria nivea) cultivars to nutrient management and planting methods. Indian Journal of Agronomy, 52 (3): 257-260.

Majumdar, B., Saha, A. R., Ghorai, A. K., Sarkar, S. K., Chowdhury, H., Kundu, D. K. and Mahapatra, B. S. 2014. Effect of fertilizer treatments on jute (Chorchorus olitorius), microbial dynamics in its rhizosphere and residual fertility status of soil. Indian Journal of Agricultural Sciences 84 (4): 503-508.

Mandal, A. K., Mandal, B. C and Ghosh, K. L. 1974. Uptake of nutrients by an improved variety of ramie (R-1452). Jute Bulletin, 37 (5-6): 68-74.

Mitra, S., Kumar, M., Saha, M. and Mahapatra, B. S. 2014. Effect of irrigation and nutrient management on growth, fibre yield and water use of ramie. Indian Journal of Agricultural Sciences, 84 (5): 595-601.

Mitra, S., Roy. A., Saha, A. R., Maitra, D. N., Sinha, M. K., Mahapatra, B. S. and Saha, S. 2010. Effect of integrated nutrient management on fibre yield, nutrient 
uptake and soil fertility in jute (Corchorus olitorius). Indian Journal of Agricultural Sciences, 80 (9): 801-804.

Mitra, S., Saha, S. Guha, B., Chakrabarti, K., Satya, P., Sharma, A. K., Gawande, S. P., Kumar, M. and Saha, M. 2013. Ramie: the strongest bast fibre of nature. Technical Buletin No. 8, ICAR-CRIJAF, Barrackpore, Kolkata, India, 38p.

Mitra, S., Singh, S., Bandyopadhyay, S. K. and Singh, C. S. 2006 Effect of irrigation, N and biofertilizers on yield and nutrient uptake by wheat. Tropical Agriculture (Trinidad), 83(3): 87-94.

Saha A.R., Mitra D.N., Mazumdar B., Saha S. and Mitra S. 2008. Effect on integrated nutrient management on roselle (Hibiscus sabdariffa) productivity its mineral nutrition and soil properties. Indian Journal of Agricultural Sciences, 78(5): 418-421.
Singh, M. V., Kumar, M., Mitra, S. and Naik, R. M. 2015. Nutrient management for jute -rice cropping system using soil test target yield equation. Journal of Applied and Natural Science, 7 (1): 211 - 214.

Singh, Y. Y. and Dhar, D. W. 2011. Changes in soil organic carbon and microbial population under organically managed rice (Oryza sativa) - wheat (Triticum aestivum) - greengram (Vigna radiata) cropping system. Indian Journal of Agricultural Sciences, 81(4): 363-365.

Subbiah, B.V. Asija, G.L. 1956. A rapid procedure for the determination of available nitrogen in soils. Current Science, 25: 259-260.

Tatar, Ö, Ilker, E., Tonk, F.A., Aygün, H.C. and Aylak, Ö. 2010. Impact of different nitrogen and potassium application on yield and fiber quality of ramie (Boehmeria nivea). International Journal of Agriculture and Biology, 12: 369-372.

\section{How to cite this article:}

Zaman, A.S.N., Biswajit Guha, Sabyasachi Mitra, S.P. Mazumdar, A.R. Saha, Mukesh Kumar, Monidipta Saha and Bandopadhyay, P. 2018. Effect of Nitrogen Management on Productivity and Mineral Nutrition of Ramie [Boehmeria nivea (L.) Gaud] and Properties of Soil. Int.J.Curr.Microbiol.App.Sci. 7(11): 2761-2769. doi: https://doi.org/10.20546/ijcmas.2018.711.317 